\title{
Effects of land use and cultivation time on soil organic and inorganic carbon storage in deep soils
}

\author{
YU Xia ${ }^{1,2,3},{ }^{*}$ ZHOU Weijian ${ }^{1,2,4,5}$, WANG Yunqiang ${ }^{1,4,5,7}$, CHENG Peng ${ }^{1,2,6,7}$, \\ HOU Yaoyao ${ }^{1,2}$, XIONG Xiaohu ${ }^{1,2}$, DU Hua ${ }^{1,2}$, YANG Ling ${ }^{1,2,3}$, WANG Ya ${ }^{1,2,3}$
}

1. State Key Laboratory of Loess and Quaternary Geology, Institute of Earth Environment, CAS, Xi'an 710061, China;

2. Shaanxi Key Laboratory of Accelerator Mass Spectrometry Technology and Application, Xi'an AMS Center, Xi'an 710061, China;

3. University of Chinese Academy of Sciences, Beijing 100049, China;

4. Interdisciplinary Research Center of Earth Science Frontier, Beijing Normal University, Beijing 100875, China;

5. CAS Center for Excellence in Quaternary Science and Global Change, Xi'an 710061, China;

6. Open Studio for Oceanic-Continental Climate and Environment Changes, Pilot National Laboratory for Marine Science and Technology (Qingdao), Qingdao 266237, Shandong, China;

7. Institute of Global Environmental Change, Xi'an Jiaotong University, Xi'an 710049, China

\begin{abstract}
The vertical distribution and exchange mechanisms of soil organic and inorganic carbon (SOC, SIC) play an important role in assessing carbon (C) cycling and budgets. However, the impact of land use through time for deep soil $C$ (below $100 \mathrm{~cm}$ ) is not well known. To investigate deep $C$ storage under different land uses and evaluate how it changes with time, we collected soil samples to a depth of $500 \mathrm{~cm}$ in a soil profile in the Gutun watershed on the Chinese Loess Plateau (CLP); and determined SOC, SIC, and bulk density. The magnitude of SOC stocks in the $0-500 \mathrm{~cm}$ depth range fell into the following ranking: shrubland $\left(17.2 \mathrm{~kg} \mathrm{~m}^{-2}\right)>$ grassland $\left(16.3 \mathrm{~kg} \mathrm{~m}^{-2}\right)>$ forestland $\left(15.2 \mathrm{~kg} \mathrm{~m}^{-2}\right)>\operatorname{cropland}(14.1 \mathrm{~kg}$ $\left.\mathrm{m}^{-2}\right)>$ gully land $\left(6.4 \mathrm{~kg} \mathrm{~m}^{-2}\right)$. The ranking for SIC stocks were: grassland $\left(104.1 \mathrm{~kg} \mathrm{~m}^{-2}\right)>$ forestland $\left(96.2 \mathrm{~kg} \mathrm{~m}^{-2}\right)>$ shrubland $\left(90.6 \mathrm{~kg} \mathrm{~m}^{-2}\right)>$ cropland $\left(82.4 \mathrm{~kg} \mathrm{~m}^{-2}\right)>$ gully land $(50.3$ $\mathrm{kg} \mathrm{m}^{-2}$ ). Respective SOC and SIC stocks were at least 1.6- and 2.1-fold higher within the $100-500 \mathrm{~cm}$ depth range, as compared to the $0-100 \mathrm{~cm}$ depth range. Overall SOC and SIC stocks decreased significantly from the 5 th to the 15th year of cultivation in croplands, and generally increased up to the 70th year. Both SOC and SIC stocks showed a turning point at 15 years cultivation, which should be considered when evaluating soil $C$ sequestration. Estimates of $C$ stocks greatly depends on soil sampling depth, and understanding the influences of land use and time will improve soil productivity and conservation in regions with deep soils.
\end{abstract}

Keywords: cultivation time; deep soil; Gutun watershed; land use; inorganic carbon; organic carbon

Received: 2019-09-20 Accepted: 2020-03-05

Foundation: The Strategic Priority Research Program of the Chinese Academy of Sciences, No.XDB40000000; National Natural Science Foundation of China, No.41730108, No.41773141, No.41573136, No.41991252; National Research Program for Key Issues in Air Pollution Control, No.DQGG0105-02

Author: Yu Xia (1988-), PhD Candidate, specialized in environmental science. E-mail: yuxia@ieecas.cn

"Corresponding author: Zhou Weijian (1963-), PhD and Professor, specialized in cosmogenic nuclides. E-mail: weijian@loess.llqg.ac.cn 


\section{Introduction}

Soils hold a large proportion of the world's carbon (C) in terrestrial ecosystems, and soils account for two-thirds of this amount, equivalent to 2-3 times the amount of $\mathrm{C}$ in the atmosphere (Trumbore, 2009; Díaz-Hernández, 2010). Soil carbon plays an active role in maintaining the global $\mathrm{C}$ balance (Xu et al., 2019). Soil $\mathrm{C}$ includes soil organic carbon (SOC) and soil inorganic carbon (SIC). These carbon reservoirs act not only as a sink, but also as a source of atmospheric $\mathrm{CO}_{2}$ (Díaz-Hernández, 2010), sensitive to climate change. SOC is especially sensitive, as SOC carbon sequestration and decomposition processes are controlled by both abiotic (e.g., climatic conditions) and biotic factors (e.g., vegetation belts, land use shifting). Lin and Zhang (2012) reported that increasing atmospheric temperature reduced SOC, whereas increasing atmospheric $\mathrm{CO}_{2}$ concentration increased SOC inventories. Increasing these by only a few parts per thousand $(0.4 \%)$ in global soils each year could remove an amount of $\mathrm{CO}_{2}$ from the atmosphere equivalent to the amount emitted by fossil-fuels in the European Union (Rumpel et al., 2018). Similar to other biotic factors, the distribution of vegetation belts and land use are expected to change under the conditions of global climate change (Adams et al., 1990; Trumbore, 1997; Wang et al., 2016), which would result in either sequestration or release of carbon in SOC. Therefore, an accurate evaluation of the amount and rate of $\mathrm{C}$ storage in soils is needed to understand the dynamics of $\mathrm{C}$ exchange between the soil and the atmosphere, and the biological influences involved.

Soil depth has a distinct influence on the amount of SOC storage (Wang et al., 2015). Global stocks of SOC and SIC are approximately 1408 Pg (Batjes, 2016) and 695 - 1738 Pg (Schlesinger, 1982) in the $0-100 \mathrm{~cm}$ soil depth range, respectively. Batjes (1996) and (Esteban et al., 2000) estimate that the global SOC stock would increase by 33\% if SOC data were extended to depths of 100-200 cm, compared to the top $100 \mathrm{~cm}$; indeed, the stock would further increase by $23 \%$ more if a depth of $300 \mathrm{~cm}$ was considered. Sommer et al. (2000) suggested that deep soils in the tropics may store large amounts of C below the uppermost $100 \mathrm{~cm}$, potentially adding another $\sim 50 \mathrm{Pg}$ to the total global $\mathrm{C}$ pool. The SIC pool has received less attention than the SOC pool in deep soils (Civeira, 2013; Han et al., 2018). As SIC is an essential component of carbon cycling in climate change models over a wide range of scales (Liu et al., 2014; Zhang et al., 2015; Civeira, 2016), it warrants increased attention. Understanding the distribution of both SOC and SIC storage in deep soil layers is necessary for assessing regional, continental, or global soil $\mathrm{C}$ storage and forecasting the consequences of global climate change.

Similarly, land use also greatly influences soil C stocks (Rumpel and Kögel-Knabner, 2011), as it affects the input and decomposition rate of organic matter in the soil (Ali et al., 2017). In deep soils, SOC has a stronger association with vegetation, because deeper root systems may cause greater changes in profiles than those caused by climate change (Esteban et al., 2000). Therefore, proper SOC management is needed for maintaining and mitigating the increasing of atmospheric $\mathrm{CO}_{2}$ (Rumpel and Kögel-Knabner, 2011; Miltner et al., 2012; Zhang et al., 2014). This requires an accurate, reliable assessment of the $\mathrm{C}$ stored deep in the soil under different land uses.

Most studies involving C-stock evaluation in different land-use types are currently based on data acquired from indirect sources, such as soil-series maps, agriculture-related reports, 
and the like (Schlesinger, 1982; Eswaran, 1993; Batjes, 1996; Zhang et al., 2004; Díaz-Hernández, 2010). For example, Chinese soil $\mathrm{C}$ budgets are usually based on the database from the Chinese Second National Soil Survey conducted in the 1980s (Zhang et al., 2004; Wang et al., 2010). Although it is easier and less expensive to sample and analyze soils to shallow depths, the lack of bulk density (BD) data for deep soils contributes to what may be a considerable error in the estimates of soil $\mathrm{C}$ reserves. Currently, most studies on soil C stocks typically extend to depths of $100 \mathrm{~cm}$, whereas only a few studies have reported SOC to depths of $300 \mathrm{~cm}$ (Harper and Tibbett, 2013; Bi et al., 2018). Plant roots in deep soils have a significant capacity to sequester $\mathrm{C}$ and thus may markedly increase soil $\mathrm{C}$ storage calculations. Data to calculate deep soil $\mathrm{C}$ reserves to depths of at least $500 \mathrm{~cm}$ are much less commonly available, although critical for improving deep-soil $\mathrm{C}$ assessments.

There is a large area and thick package of loess $\left(640,000 \mathrm{~km}^{2}\right)$ in northwest China, called the Chinese Loess Plateau (CLP), which holds $1239.85 \mathrm{Tg}$ of C to a depth of $20 \mathrm{~cm}$ (Fu et al., 2014). In order to meet food requirements for the growing human population, land reclamation started in the 1950 's, whereby approximately $336 \mathrm{~km}^{2}$ of cropland was opened by 2012, partly under the well-known "Grain for Green" program that has been supported since 1999 by the central government of the People's Republic of China. Since then, several studies have been conducted to elucidate the effect of land cultivation on soil C stocks. Some researchers studied SOC and SIC stocks under grassland, forestland, and shrubland at different restoration times (Wang et al., 2016; Liu et al., 2017). The results of such studies showed that SIC decreased, while SOC increased with vegetation restoration. Jaiarree et al. (2011) reported that SOC stocks were reduced by $47 \%$ after 12 years of cultivation. However, studies of SOC and SIC over time of cultivation in reclaimed croplands are lacking. Estimating the changes in deep soil $\mathrm{C}$ storage under reclaimed croplands at different timescales would complement those findings and facilitate refined estimates of SOC and SIC stocks, which in turn can be associated with fixed atmospheric $\mathrm{CO}_{2}$.

Therefore, the objective of this research is to investigate deep SOC and SIC stocks under cropland, forestland, grassland, shrubland and gully land types over 70 years following reclamation of croplands. In particular, we address the following key questions:

1) How do SOC and SIC stocks change with soil depth under five land-use types?

2) How do these deep-soil C stocks respond to different land-use types?

3) Which land use is optimal for $\mathrm{C}$ storage in our study area?

4) How do these stocks vary with time?

\section{Material and methods}

\subsection{Study site}

The Gutun watershed $\left(36^{\circ} 46^{\prime} 39^{\prime \prime}-37^{\circ} 03^{\prime} 34^{\prime \prime} \mathrm{N}, 109^{\circ} 41^{\prime} 02^{\prime \prime}-109^{\circ} 56^{\prime} 58^{\prime \prime} \mathrm{E}\right)$ on the Chinese Loess Plateau (CLP) covers approximately $24 \mathrm{~km}^{2}, 46 \mathrm{~km}$ east of Yan'an city in Shaanxi Province (Figure 1). The study area is characterized by a temperate sub-humid climate with annual mean temperature and precipitation of $9.7^{\circ} \mathrm{C}$ and $541 \mathrm{~mm}$, respectively; most of the precipitation occurs between June and September (Zhao et al., 2019).

In all, 21 representative profiles within the Gutun watershed were categorized based on predominant land use as grassland (two profiles), shrubland (one profile), forestland (two 
Figure 1 Location of the study area and sampling points ( $n=21$ profiles) under different land use types within the Gutun watershed. Cropland includes five restoration time frames: RC-5 (light blue star), RC-15 (light green star), RC-35 (yellow star), RC-60 (red star), RC-70 (black star).

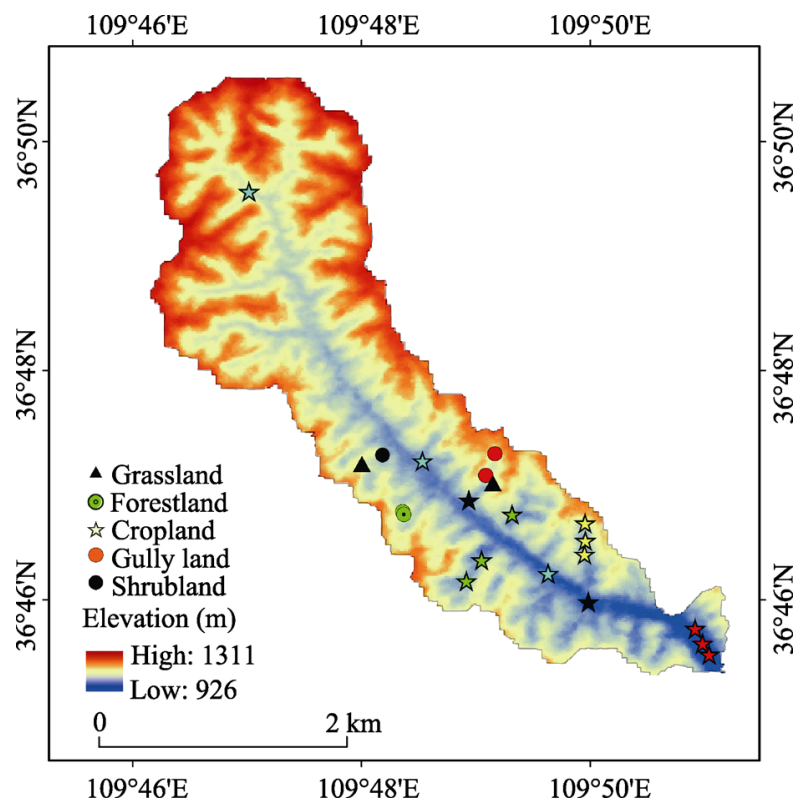

profiles), cropland (14 profiles), and gully land (two profiles), through field surveys, a work of time consuming and costly. Figure 1 shows that all grassland, shrubland, and forestland profiles were collected from the ridge, and there are several similar ridges in our study area. Moreover, cropland included five communities at different stages of cultivation, such as RC5 (three profiles), RC15 (three profiles), RC35 (three profiles), RC60 (three profiles), and RC70 (two profiles). Limited by a vast, hilly-gully area and drought, local governments and farmers had to open wasteland for cultivation by cutting mountain ridges to solve food shortages, resulting in a series of unique cropland sequences. We verified the cultivation age by interviewing local elders. The selected five cropland sites have been identified under continued cultivation for 5, 15, 35, 60, and at least 70 years (Figure 1).

\subsection{Soil sampling and laboratory analysis}

Soil samples were collected from $1 \mathrm{~m} \times 1 \mathrm{~m}$ quadrats located by GPS from March to April in 2017. The litter in each site was cleared before sampling. Every site was excavated to a depth of $500 \mathrm{~cm}$, or until the calcification layer or overflow layer was reached. We used 421 sampling points located on the ridges to determine bulk density (BD) at $10 \mathrm{~cm}$ intervals in the $0-20 \mathrm{~cm}$ top-soil layer, and at $20 \mathrm{~cm}$ intervals at depths from 20 to $500 \mathrm{~cm}$. Another 421 samples were collected to determine total carbon (TC), SIC, soil water content (SWC), and particle composition.

A portion of each soil sample was used to measure SWC gravimetrically from weight loss after drying at $105^{\circ} \mathrm{C}$ (Wang et al., 2016). The remaining soil in each sample was air-dried and then sieved through a $2 \mathrm{~mm}$ mesh after removing debris. Soil texture was determined by laser diffraction using a Mastersizer 3000 (Malvern Instruments, England). The total carbon (TC) was measured by using an elemental analyzer at a combustion temperature of $950^{\circ} \mathrm{C}$ (Vario EL cube, Elemental Analyzer, Elementar, Germany). As SIC refers to the carbonate minerals in the soil, such as $\mathrm{CaCO}_{3}, \mathrm{MgCO}_{3}$ (Wu et al., 2009; Liu et al., 2017), SIC content was measured by acid hydrolysis, which released SIC as $\mathrm{CO}_{2}$. Finally, SOC content was calculated by subtraction of SIC content from TC content. All the experiments were performed at the Xi' an Accelerator Mass Spectrometry Center.

\subsection{Calculation of SOC storage and SIC storage}

Stored SOC and SIC $\left(\mathrm{kg} \mathrm{m}^{-2}\right)$ were calculated using the following equations (Grimm et al., 
2008):

$$
\begin{aligned}
S O C_{\text {stock }} & =S O C \times B D \times\left(1-F_{\text {contet }}\right) \times \Delta d \times 0.01 \\
S I C_{\text {stock }} & =S I C \times B D \times\left(1-F_{\text {contet }}\right) \times \Delta d \times 0.01
\end{aligned}
$$

where, $S O C_{\text {stock }}$ and $S I C_{\text {stock }}$ represent SOC and SIC storage, respectively; SOC and SIC are the SOC and SIC contents $\left(\mathrm{g} \mathrm{kg}^{-1}\right)$, respectively; BD is the soil bulk density $\left(\mathrm{g} \mathrm{cm}^{-3}\right)$; the occurrence of coarse fragments in the loessal soils of the Chinese Loess Plateau is rare, therefore, $F_{\text {content }}$ is usually negligible in the CLP; $\Delta d$ represents the soil layer thickness $(\mathrm{cm})$.

Two-way ANOVA analysis was applied to determine the significance of any effects from land use and cropland reclamation time on SOC, SIC and the other parameters under study. All the differences were evaluated at a significance level of 0.05 . Statistical analyses were performed using Origin 2018b, SPSS 22, Sigmaplot 12.5 and Figures of sampling sites were drawn by ArcMap 10.2 software.

\section{Results}

\subsection{Soil basic characteristics}

Table 1 shows that soil texture was similar in all soil layers under the five land-use types studied. Both the highest proportion of silt and clay content and the lowest sand content were found in gully land soils. Silt content increased gradually with soil depth, whereas sand content decreased.

Table 1 Soil properties under five land-use types in the Gutun watershed on the Chinese Loess Plateau

\begin{tabular}{lccccccc}
\hline \multirow{2}{*}{$\begin{array}{c}\text { Land-use } \\
\text { type }\end{array}$} & \multicolumn{5}{c}{ Texture (\%) } & & \\
\cline { 2 - 7 } & \multicolumn{1}{c}{ Sand } & Silt & Clay & & & \\
\hline Grassland & $19.2 \pm 3.8 \mathrm{ab}$ & $78.2 \pm 3.6 \mathrm{a}$ & $2.6 \pm 0.3 \mathrm{bc}$ & $1.3 \pm 0.1 \mathrm{~b}$ & $126.0 \pm 20.3 \mathrm{~b}$ & $2.96 \pm 2.22 \mathrm{a}$ & $16.77 \pm 3.00 \mathrm{a}$ \\
Shrubland & $19.7 \pm 3.0 \mathrm{ab}$ & $77.6 \pm 2.8 \mathrm{a}$ & $2.7 \pm 0.4 \mathrm{bc}$ & $1.3 \pm 0.1 \mathrm{~b}$ & $92.8 \pm 47.5 \mathrm{c}$ & $2.76 \pm 1.75 \mathrm{ab}$ & $13.79 \pm 2.40 \mathrm{bc}$ \\
Forestland & $22.3 \pm 4.5 \mathrm{a}$ & $75.4 \pm 4.3 \mathrm{a}$ & $2.3 \pm 0.4 \mathrm{c}$ & $1.3 \pm 0.1 \mathrm{~b}$ & $71.7 \pm 19.4 \mathrm{c}$ & $2.58 \pm 1.22 \mathrm{ab}$ & $14.82 \pm 1.81 \mathrm{ab}$ \\
Cropland & $22.1 \pm 5.4 \mathrm{a}$ & $75.1 \pm 5.0 \mathrm{a}$ & $2.8 \pm 0.7 \mathrm{~b}$ & $1.5 \pm 0.2 \mathrm{ab}$ & $177.2 \pm 51.6 \mathrm{a}$ & $2.04 \pm 1.10 \mathrm{ab}$ & $12.38 \pm 3.18 \mathrm{c}$ \\
Gully land & $18.6 \pm 4.2 \mathrm{~b}$ & $78.2 \pm 3.8 \mathrm{a}$ & $3.2 \pm 0.6 \mathrm{a}$ & $1.4 \pm 0.1 \mathrm{a}$ & $197.7 \pm 31.0 \mathrm{a}$ & $1.84 \pm 1.29 \mathrm{~b}$ & $14.22 \pm 2.65 \mathrm{bc}$ \\
\hline
\end{tabular}

*BD, bulk density; SWC, soil water content; SOC, soil organic carbon; SIC, soil inorganic carbon. Different lowercase letters within columns indicate significant differences among land-use types.

\subsection{Carbon content under different land uses and various times of cropland cultivation}

The variability of $\mathrm{BD}$ was small $(<10 \%)$ throughout the soil profile under each land-use type, but overall, it increased with depth. Cropland showed the highest BD values, ranging from 1.01 to $1.82 \mathrm{~g} \mathrm{~cm}^{-3}$, followed by gully land. Shrubland, forestland, and grassland were comparable in $\mathrm{BD}$, with uniformly low levels (Table 1).

Land use significantly affected SWC $(p<0.05)$, with the following ranking: gully land > cropland $>$ grassland $>$ shrubland $>$ forestland (Table 1). There were obvious changes in SWC between top and deep soil layers; SWC increased with depth in gully land and croplands, in agreement with most farmland in China (Zhu et al., 2019), whereas in forestland, it varied over a wide range and decreased to $<100 \mathrm{~g} \mathrm{~kg}^{-1}$ below $40 \mathrm{~cm}$ depth, which is classified as a dried soil layer (Wang et al., 2004).

The mean SOC of all 21 soil profiles and the $0-500 \mathrm{~cm}$ soil profile was $2.24 \pm 1.39 \mathrm{~g} \mathrm{~kg}^{-1}(n=$ 

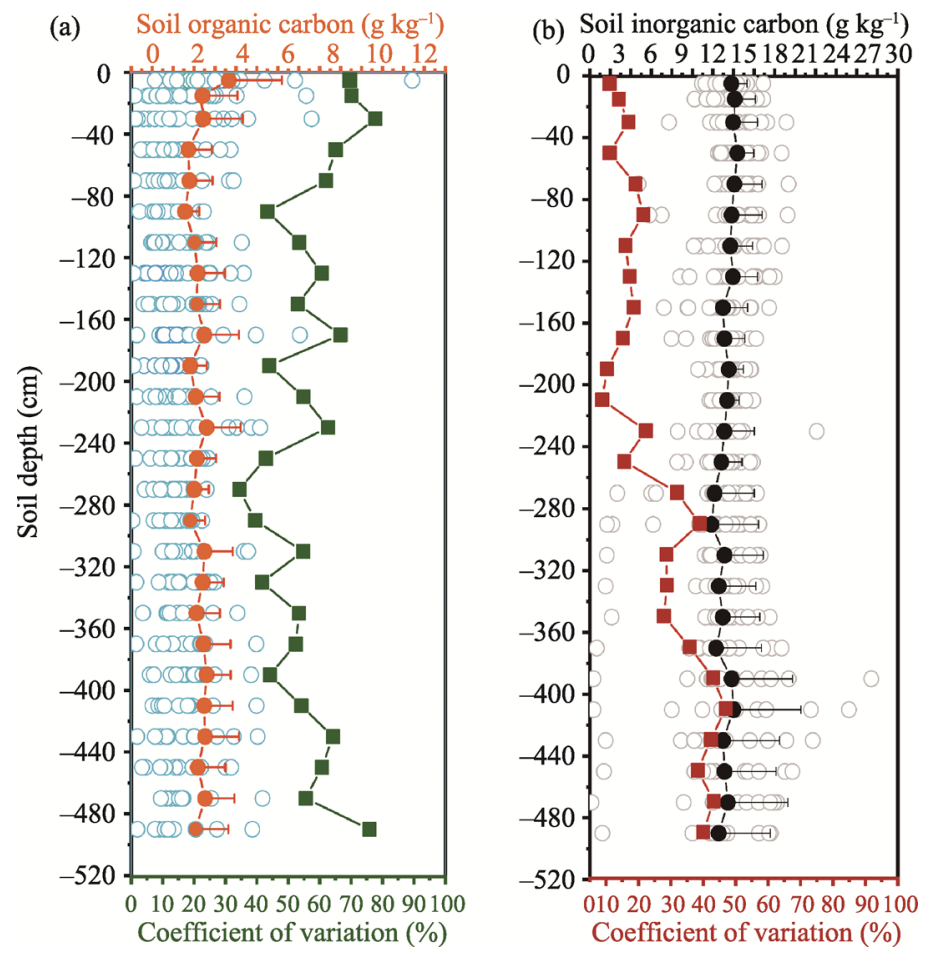

Figure 2 Vertical distribution of SOC and SIC along 500-cm deep soil profiles. (a) SOC content (open blue circles), means (closed red circles), and the coefficient of variations (green squares); (b) SIC content (open light grey circles), means (closed black circles), and the coefficient of variations (dark red squares).

421), which is lower than values measured at other sites in the CLP (Ma et al., 2012; Wang et al., 2016; Liu et al., 2017). Overall, surface SOC was higher than that in the subsoil (Figure 2). Land use influenced SOC content significantly $(p<0.05)$ (Table 2). In grassland, forestland, and shrubland, SOC values were generally higher than those in cropland or gully land in the same soil layers (Table 3). Grasslands were exceptional in that SOC of the $0-60 \mathrm{~cm}$ layer, which was significantly higher than that in the 60-500 $\mathrm{cm}$ layer $(p<0.05)$, while no such difference was observed for shrubland, forestland, or gully land $(p>0.05)$ (Table 3$)$.

Cultivation time influenced SOC content significantly $(p<0.05)$ (Table 2$)$. The corresponding overall mean SOC content for the $500 \mathrm{~cm}$ soil profile decreased in the following order: RC70 > RC35 > RC5 > RC60 > RC15 (Table 4). R15 had the lowest SOC content, which may be caused by agricultural disturbance and rainfall, summer rainfall especially can accelerate the transport of soil organic matter (Zeng et al., 2019). Additionally, SOC content was significantly influenced by soil depth $(p<0.05)$ (Table 2); thus, SOC content in the uppermost soil layers was higher than that in deeper layers, especially under RC35 and RC70. We also observed that SOC content was basically unchanged (estimated at every $100 \mathrm{~cm}$ interval), from 100 to $500 \mathrm{~cm}$ depth, under five reclaimed croplands. Furthermore, SOC content from 100 to $500 \mathrm{~cm}$ depth was significantly higher under RC5, RC35, and RC70 than under RC15 or RC60.

In general, SIC was found to be much higher than SOC in this study, ranging from 0.17 to $27.4 \mathrm{~g} \mathrm{~kg}^{-1}$. Average SIC was $13.4 \mathrm{~g} \mathrm{~kg}^{-1}$, with a relatively small coefficient of variation of $24.8 \%$; further, the mean SIC content was approximately six times greater that of the corre- 
sponding SOC content. Mean SIC content decreased with depth along the 0-500 cm profile, with deeper soil layers containing slightly lower amounts of SIC than the overlying layers (Figure 2). In line with SOC, grasslands also showed the highest mean SIC; further, SIC content in grassland and shrubland was significantly higher than in any other land-use type $(p<0.05)$ (Tables 1 and 3). SIC was significantly influenced by cultivation time over 70 years $(p<0.05)$ (Table 2$)$, with RC15 showing extremely low SIC values in the $300-500 \mathrm{~cm}$ depth interval (Table 4).

Table 2 Two-way ANOVA* F and $p$-values for land-use type, cultivation time, and soil depth effects on soil BD $\left(\mathrm{g} \mathrm{cm}^{-3}\right)$, SWC $\left(\mathrm{g} \mathrm{kg}^{-1}\right)$, SOC content $\left(\mathrm{g} \mathrm{kg}^{-1}\right)$, SIC content $\left(\mathrm{g} \mathrm{kg}^{-1}\right)$, SOC stocks $\left(\mathrm{kg} \mathrm{m}^{-2}\right)$, and SIC stocks $\left(\mathrm{kg} \mathrm{m}^{-2}\right)$ in Gutun watershed

\begin{tabular}{|c|c|c|c|c|c|c|c|c|c|c|c|c|}
\hline \multirow{2}{*}{$\begin{array}{l}\text { Factor of } \\
\text { variation }\end{array}$} & \multicolumn{2}{|c|}{$\mathrm{BD}$} & \multicolumn{2}{|c|}{ SWC } & \multicolumn{2}{|c|}{ SOC } & \multicolumn{2}{|c|}{ SIC } & \multicolumn{2}{|c|}{ SOCS } & \multicolumn{2}{|c|}{ SICS } \\
\hline & $\mathrm{F}$ & $p$ & $\mathrm{~F}$ & $p$ & $\mathrm{~F}$ & $p$ & $\mathrm{~F}$ & $p$ & $\mathrm{~F}$ & $p$ & $\mathrm{~F}$ & $p$ \\
\hline Land-use types & 24.32 & 0.000 & 79.060 & 0.000 & 11.852 & 0.000 & 25.320 & 0.000 & 3.452 & 0.009 & 6.222 & 0.000 \\
\hline Soil depth & 2.310 & 0.033 & 6.080 & 0.000 & 4.434 & 0.000 & 2.121 & 0.000 & 4.651 & 0.000 & 17.781 & 0.000 \\
\hline Time & 112.59 & 0.000 & 36.283 & 0.000 & 18.082 & 0.000 & 31.666 & 0.000 & 21.867 & 0.000 & 13.365 & 0.000 \\
\hline
\end{tabular}

Note: Analysis of variance; BD, bulk density; SWC, soil water content; SOC, soil organic carbon; SIC, soil inorganic carbon

Table 3 Vertical distribution of SOC and SIC contents $\left(\mathrm{g} \mathrm{kg}^{-1}\right)$ under five land-use types

\begin{tabular}{cccccccc}
\hline Depth $(\mathrm{cm})$ & $0-20$ & $20-60$ & $60-100$ & $100-200$ & $200-300$ & $300-400$ & $400-500$ \\
\hline Grassland & $7.26 \pm 4.56 \mathrm{aA}$ & $3.93 \pm 3.05 \mathrm{aAB}$ & $2.38 \pm 0.93 \mathrm{aB}$ & $2.51 \pm 1.12 \mathrm{aB}$ & $3.09 \pm 1.68 \mathrm{aB}$ & $2.27 \pm 0.61 \mathrm{aB}$ & $1.88 \pm 1.35 \mathrm{bB}$ \\
Shrubland & $3.79 \pm 1.52 \mathrm{abA}$ & $1.55 \pm 0.8 \mathrm{aB}$ & $1.07 \pm 0.2 \mathrm{aB}$ & $2.89 \pm 2.71 \mathrm{aA}$ & $2.71 \pm 1.25 \mathrm{abA}$ & $1.77 \pm 0.58 \mathrm{aB}$ & $4.40 \pm 1.33 \mathrm{aA}$ \\
SOC Forestland & $3.29 \pm 0.94 \mathrm{abA}$ & $2.90 \pm 1.57 \mathrm{aA}$ & $2.38 \pm 1.49 \mathrm{aA}$ & $2.08 \pm 0.89 \mathrm{aA}$ & $2.39 \pm 0.84 \mathrm{abA}$ & $3.19 \pm 1.61 \mathrm{aA}$ & $2.03 \pm 0.51 \mathrm{bA}$ \\
Cropland & $2.52 \pm 1.25 \mathrm{bA}$ & $1.81 \pm 1.25 \mathrm{aAB}$ & $1.46 \pm 0.63 \mathrm{aB}$ & $1.99 \pm 1.05 \mathrm{aAB}$ & $1.89 \pm 0.86 \mathrm{bAB} 2.34 \pm 1.07 \mathrm{aAB}$ & $2.22 \pm 1.30 \mathrm{bAB}$ \\
Gully land & $1.68 \pm 1.27 \mathrm{bA}$ & $1.61 \pm 1.14 \mathrm{aA}$ & $2.03 \pm 1.57 \mathrm{aA}$ & $2.26 \pm 1.77 \mathrm{aA}$ & $1.42 \pm 0.39 \mathrm{bA}$ & \\
\hline Grassland & $14.97 \pm 1.39 \mathrm{abB}$ & $17.2 \pm 2.0 \mathrm{abAB}$ & $17.4 \pm 2.2 \mathrm{abAB}$ & $16.25 \pm 0.92 \mathrm{aB}$ & $14.18 \pm 1.86 \mathrm{aB}$ & $17.45 \pm 3.7 \mathrm{aAB}$ & $20.18 \pm 2.58 \mathrm{aA}$ \\
Shrubland & $16.91 \pm 0.01 \mathrm{aA}$ & $16.55 \pm 0.21 \mathrm{aA}$ & $16.45 \pm 0.07 \mathrm{aA}$ & $14.3 \pm 2.9 \mathrm{abAB}$ & $13.31 \pm 1.13 \mathrm{aB}$ & $13.21 \pm 1.01 \mathrm{bB}$ & $10.96 \pm 1.44 \mathrm{bB}$ \\
SIC Forestland & $14.27 \pm 1.37 \mathrm{abA}$ & $13.97 \pm 1.96 \mathrm{abA}$ & $14.42 \pm 1.61 \mathrm{abA}$ & $14.75 \pm 1.12 \mathrm{abA}$ & $14.57 \pm 1.20 \mathrm{aA}$ & $14.76 \pm 2.63 \mathrm{aA}$ & $17.01 \pm 0.53 \mathrm{abA}$ \\
Cropland & $13.40 \pm 1.61 \mathrm{bA}$ & $13.39 \pm 1.44 \mathrm{bA}$ & $13.05 \pm 2.77 \mathrm{bA}$ & $12.68 \pm 1.69 \mathrm{bA}$ & $11.99 \pm 3.47 \mathrm{aA}$ & $11.52 \pm 4.16 \mathrm{bA}$ & $11.34 \pm 5.04 \mathrm{bA}$ \\
Gully land & $15.10 \pm 1.40 \mathrm{abA}$ & $15.66 \pm 1.72 \mathrm{abA}$ & $14.91 \pm 1.07 \mathrm{abA}$ & $14.17 \pm 2.86 \mathrm{abA}$ & $11.88 \pm 3.68 \mathrm{aA}$ & & \\
\hline
\end{tabular}

Note: different lowercase letters within columns indicate significant differences among land use types $(p<0.05)$; different uppercase letters within rows indicate significant differences among different soil layers in the same land-use type $(p<0.05)$.

Table 4 Vertical distribution of SOC and SIC contents $\left(\mathrm{g} \mathrm{kg}^{-1}\right)$ from RC5 to RC70 croplands in Gutun watershed

\begin{tabular}{|c|c|c|c|c|c|c|c|}
\hline $\begin{array}{c}\text { Depth } \\
(\mathrm{cm})\end{array}$ & $0-20$ & $20-60$ & $60-100$ & $100-200$ & $200-300$ & $300-400$ & $400-500$ \\
\hline RC5 & $2.02 \pm 1 \mathrm{aAB}$ & $1.41 \pm 0.94 \mathrm{bB}$ & $1.63 \pm 0.78 \mathrm{aAB}$ & $2.35 \pm 0.96 \mathrm{abAB}$ & $1.87 \pm 0.35 \mathrm{bcAB}$ & $2.96 \pm 0.48 \mathrm{abA}$ & $2.6 \pm 0.77 \mathrm{aAB}$ \\
\hline $\mathrm{RC} 15$ & $1.82 \pm 0.5 \mathrm{bA}$ & $1.51 \pm 1.82 \mathrm{bA}$ & $1.13 \pm 0.66 \mathrm{aA}$ & $1.45 \pm 0.88 \mathrm{bA}$ & $1.3 \pm 0.89 \mathrm{cA}$ & $1 \pm 0.76 \mathrm{cA}$ & $0.72 \pm 0.53 \mathrm{bA}$ \\
\hline SOC RC35 & $3.3 \pm 0.83 \mathrm{aA}$ & $2.4 \pm 1.07 \mathrm{aAB}$ & $1.69 \pm 0.26 \mathrm{aB}$ & $2.12 \pm 0.43 \mathrm{abAB}$ & $2.34 \pm 0.53 \mathrm{abAB}$ & $2.49 \pm 0.43 \mathrm{abAB}$ & $2.9 \pm 1.5 \mathrm{aAB}$ \\
\hline RC60 & $2.61 \pm 1.96 \mathrm{aA}$ & $1.61 \pm 1.14 \mathrm{bA}$ & $5 \mathrm{aA}$ & $1.69 \pm 0.45 \mathrm{bA}$ & $1.79 \pm 0.6 \mathrm{cA}$ & $2.35 \pm 1.28 \mathrm{bA}$ & $2.03 \pm 1.31 \mathrm{abA}$ \\
\hline $\mathrm{RC} 70$ & $3.04 \pm 1.18 \mathrm{aAB}$ & $2.26 \pm 1.25 \mathrm{aAB}$ & $1.50 \pm 0.57 \mathrm{aB}$ & $2.66 \pm 1.90 \mathrm{aAB}$ & $3.03 \pm 1.02 \mathrm{aAB}$ & $3.45 \pm 0.77 \mathrm{aA}$ & \\
\hline $\mathrm{RC5}$ & $11.95 \pm 1.41 \mathrm{bA}$ & $12.47 \pm 2.5 \mathrm{aA}$ & $12.66 \pm 2.9 \mathrm{abA}$ & $12.29 \pm 1.67 \mathrm{bA}$ & $13.56 \pm 1.45 \mathrm{aA}$ & $12.9 \pm 1.64 \mathrm{aA}$ & $99 \mathrm{aA}$ \\
\hline $\mathrm{RC} 15$ & $14.07 \pm 2.21 \mathrm{abA}$ & $14.29 \pm 1.2 \mathrm{aA}$ & $14.31 \pm 1.11 \mathrm{aA}$ & $12.83 \pm 1 \mathrm{bAB}$ & $10.46 \pm 5.41 \mathrm{aAB}$ & $6.16 \pm 5.2 \mathrm{bBC}$ & $0.94 \pm 0.63 \mathrm{bC}$ \\
\hline SIC RC3 & $1364+037 \mathrm{ab}$ & $13.44 \pm 0.73 \mathrm{aA}$ & $14.39 \pm 1.09 \mathrm{aA}$ & $13.5 \pm 0.51 \mathrm{bA}$ & $13.12 \pm 1 \mathrm{aA}$ & $12.99 \pm 1.82 \mathrm{aA}$ & $14.13 \pm 3.16 \mathrm{aA}$ \\
\hline RC60 & $14.65 \pm 1.39 \mathrm{aA}$ & $13.52 \pm 0.93 \mathrm{aAB}$ & $3.32 \pm 0.83 \mathrm{abAB}$ & $13.17 \pm 0.94 \mathrm{bAB}$ & $12.33 \pm 0.9 \mathrm{aB}$ & $13.26 \pm 1.93 \mathrm{aAB}$ & $12.9 \pm 1.26 \mathrm{aAB}$ \\
\hline $\mathrm{RC} 70$ & $12.35 \pm 0.25 \mathrm{abA}$ & $13.13 \pm 0.82 \mathrm{aA}$ & $9.65 \pm 5.08 \mathrm{bA}$ & $16.43 \pm 3.24 \mathrm{aA}$ & $10.53 \pm 3.87 \mathrm{aA}$ & $13.09 \pm 1.48 \mathrm{aA}$ & \\
\hline
\end{tabular}

Note: different lowercase letters within columns indicate significant differences among five reclamation times $(p<$ $0.05)$, while different uppercase letters indicate significant differences between different soil layers at the same reclamation time $(p<0.05)$. 


\subsection{Carbon storage under different land uses and various reclamation times of croplands}

\subsubsection{SOC stocks}

Overall, SOC reserves were relatively small in the $0-500 \mathrm{~cm}$ soil profile; accounting for $11-16 \%$ of the TC stocks, and decreasing abundances as follows: shrubland $\left(17.2 \mathrm{~kg} \mathrm{~m}^{-2}\right)$ $>$ grassland $\left(16.2 \mathrm{~kg} \mathrm{~m}^{-2}\right)>$ forestland $\left(15.2 \mathrm{~kg} \mathrm{~m}^{-2}\right)>$ cropland $\left(14.1 \mathrm{~kg} \mathrm{~m}^{-2}\right)>$ gully land $\left(6.37 \mathrm{~kg} \mathrm{~m}^{-2}\right.$ ) (Figure 3). The spatial distribution of the integral SOC stocks under five land uses are shown in Figure 4a. It shows gully land sites and RC15 had the lowest SOC stocks, while land with natural vegetation tended to have higher SOC stocks (Fig-

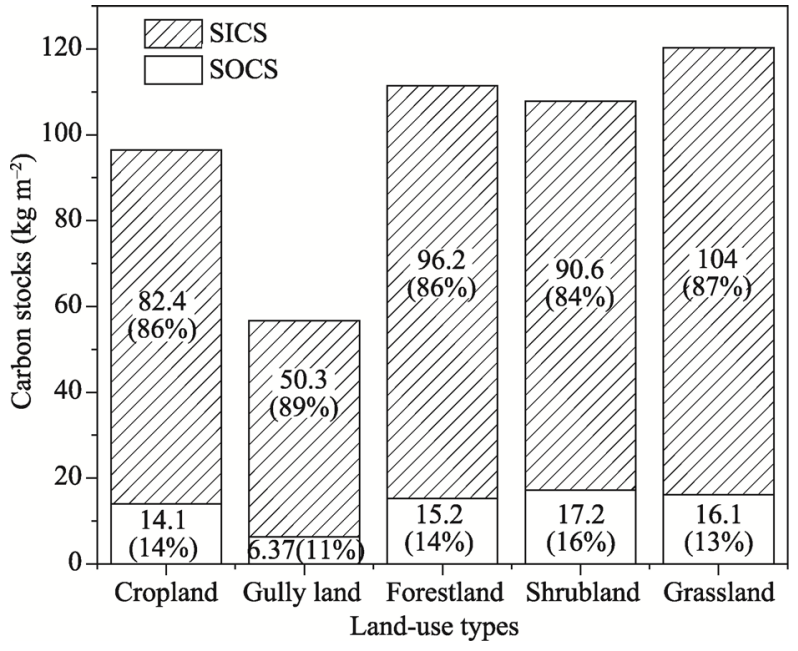

Figure 3 Percentage of SOC and SIC stocks in $0-500-\mathrm{cm}$ soil profiles for five land-use types ure $4 \mathrm{a})$. The proportion of $\mathrm{C}$ below $100 \mathrm{~cm}$ depth accounted for approximately $87 \%, 71 \%, 78 \%, 82 \%$, and $62 \%$ of the integral SOC $(0-500$ $\mathrm{cm}$ ) under the five land-use types studied, in the order given above. SOC was concentrated in the grassland surface soils, which was consistent with that of Bi et al. (2018). Figure 5a shows that the SOC stock in the $0-20 \mathrm{~cm}$ top layer was significantly higher than those in the $400-500 \mathrm{~cm}$ interval $(p<0.05)$. In contrast, the vertical distribution pattern in shrublands reached deeper, with more SOC stored in the subsoil (Figure 5b).

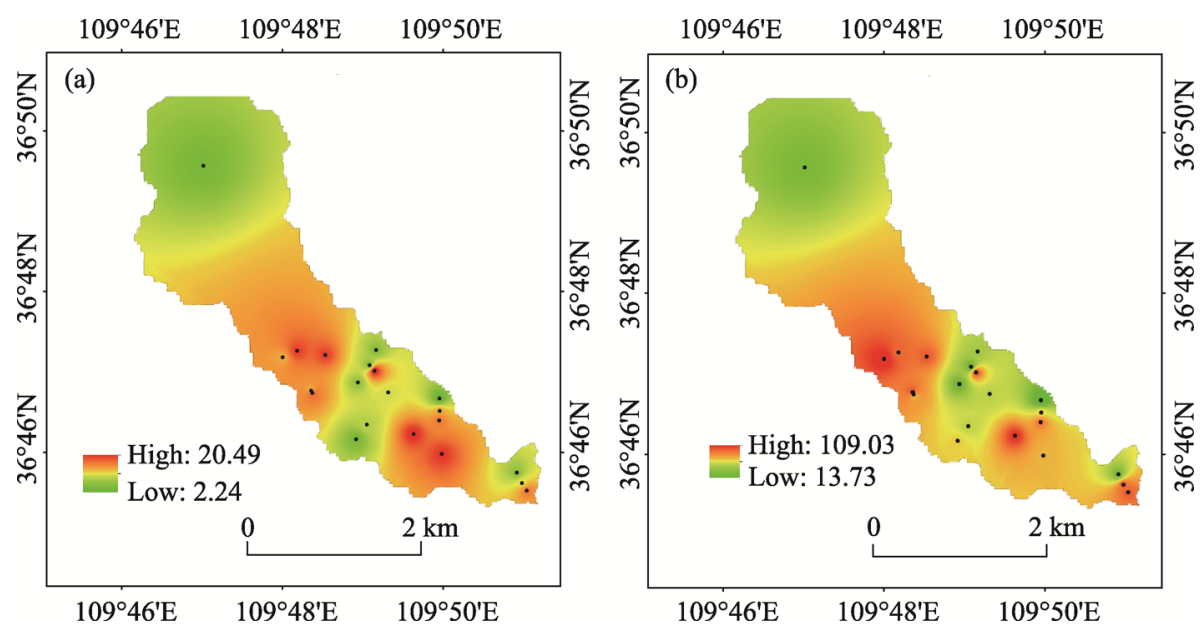

Figure 4 Spatial distribution of soil organic carbon stocks (a) and soil inorganic carbon stocks (b) in Gutun watershed 


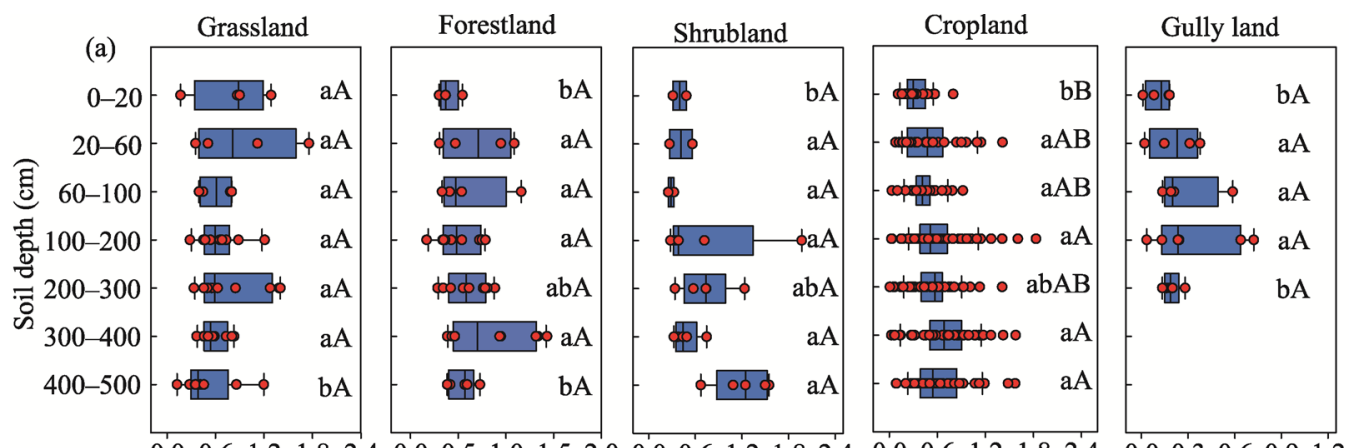

$\begin{array}{llllllllllllllllllllllllllll}0.0 & 0.6 & 1.2 & 1.8 & 2.4 & 0.0 & 0.5 & 1.0 & 1.5 & 2.0 & 0.0 & 0.6 & 1.2 & 1.8 & 2.4 & 0.0 & 0.6 & 1.2 & 1.8 & 2.4 & 0.0 & 0.3 & 0.6 & 0.9 & 1.2\end{array}$

SOC stock $\left(\mathrm{kg} \mathrm{m}^{-2}\right)$

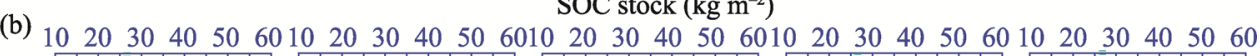
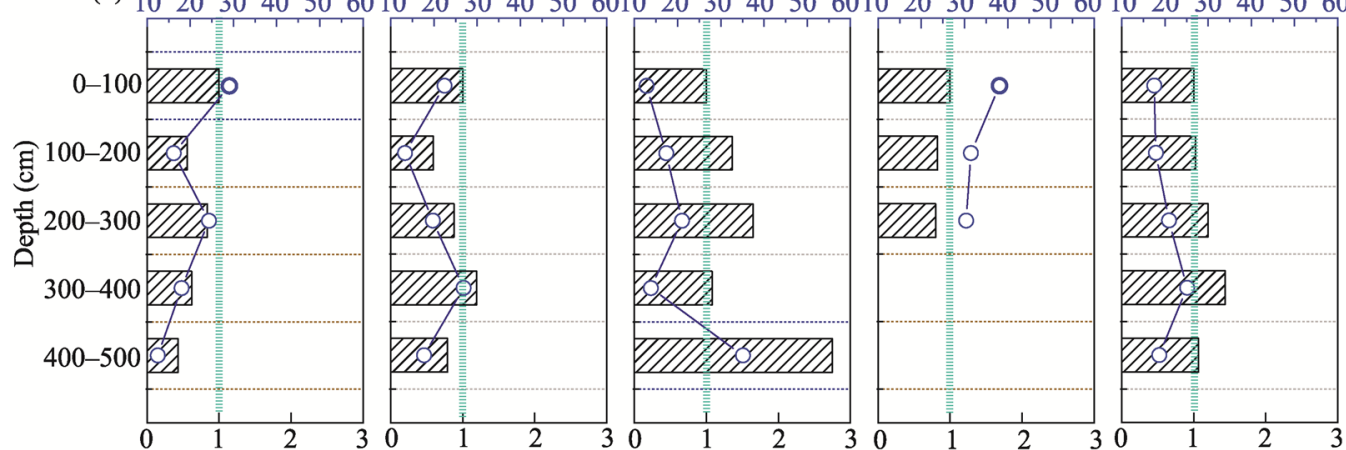

(c) Grassland

Forestland
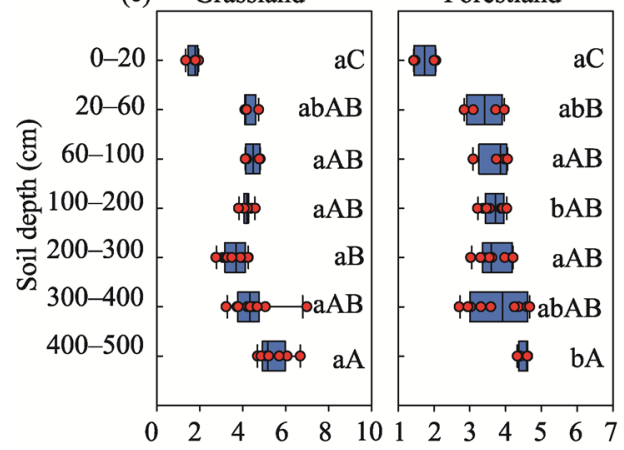

Shrubland

Cropland

Gully land
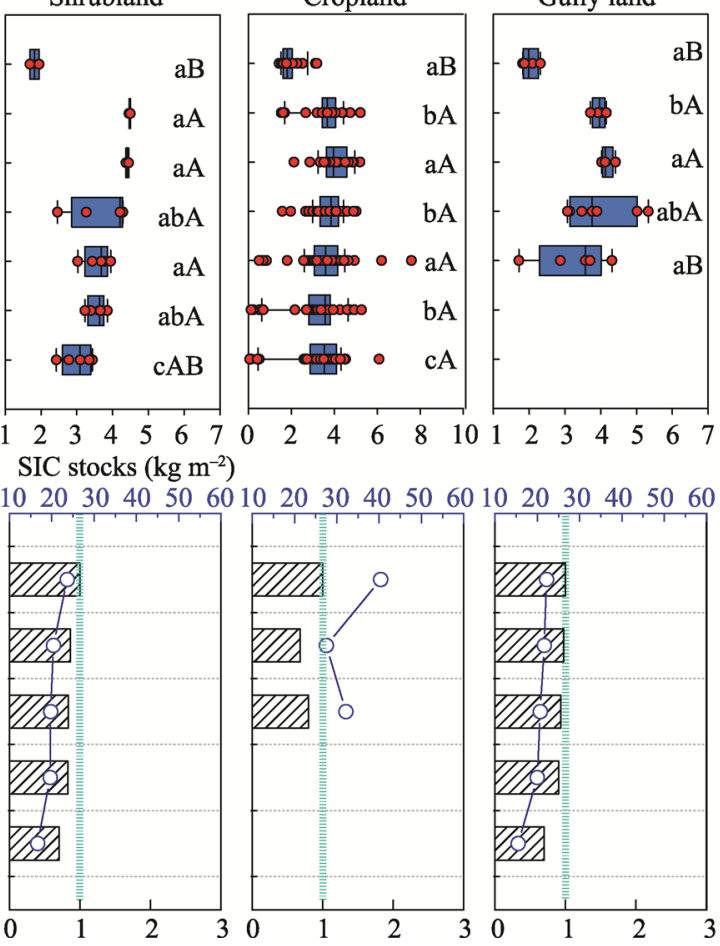

(d)
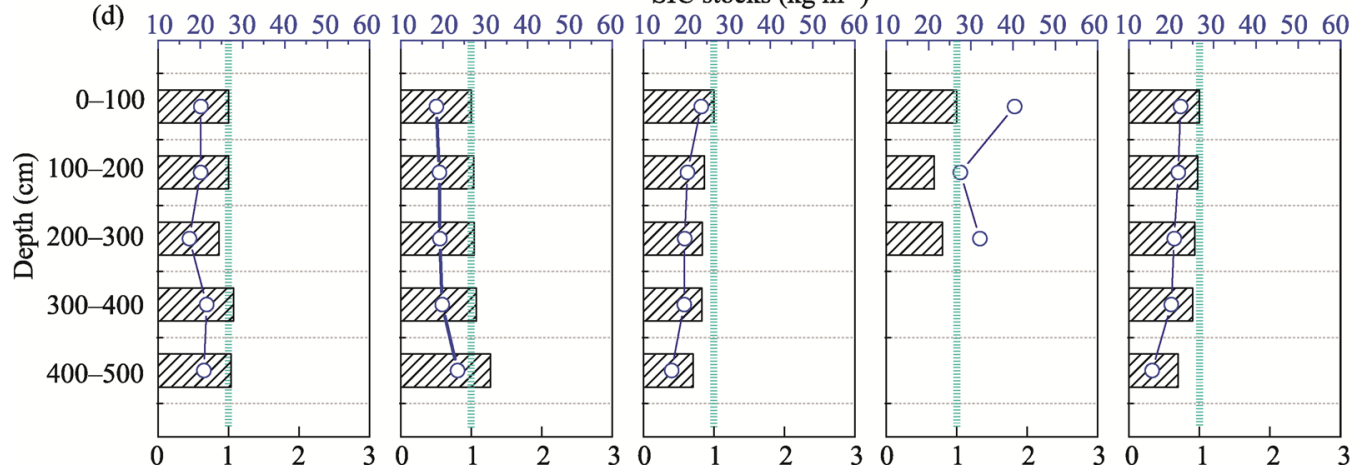

Figure 5 Soil carbon stocks. (a) SOC stock; (c) SIC stock. (b) and (d) showed the percentage within the bars are proportions of stocks in a $100-\mathrm{cm}$ thick layer compared to the upper $100 \mathrm{~cm}$. Blue circles represent the ratio of the carbon stocks in a given $100-\mathrm{cm}$ layer to the $0-500 \mathrm{~cm}$ complete profile. Different lowercase letters indicate significant differences among land uses $(p<0.05)$, while uppercase letters indicate significant differences among different soil layers within the same land-use type $(p<0.05)$. 

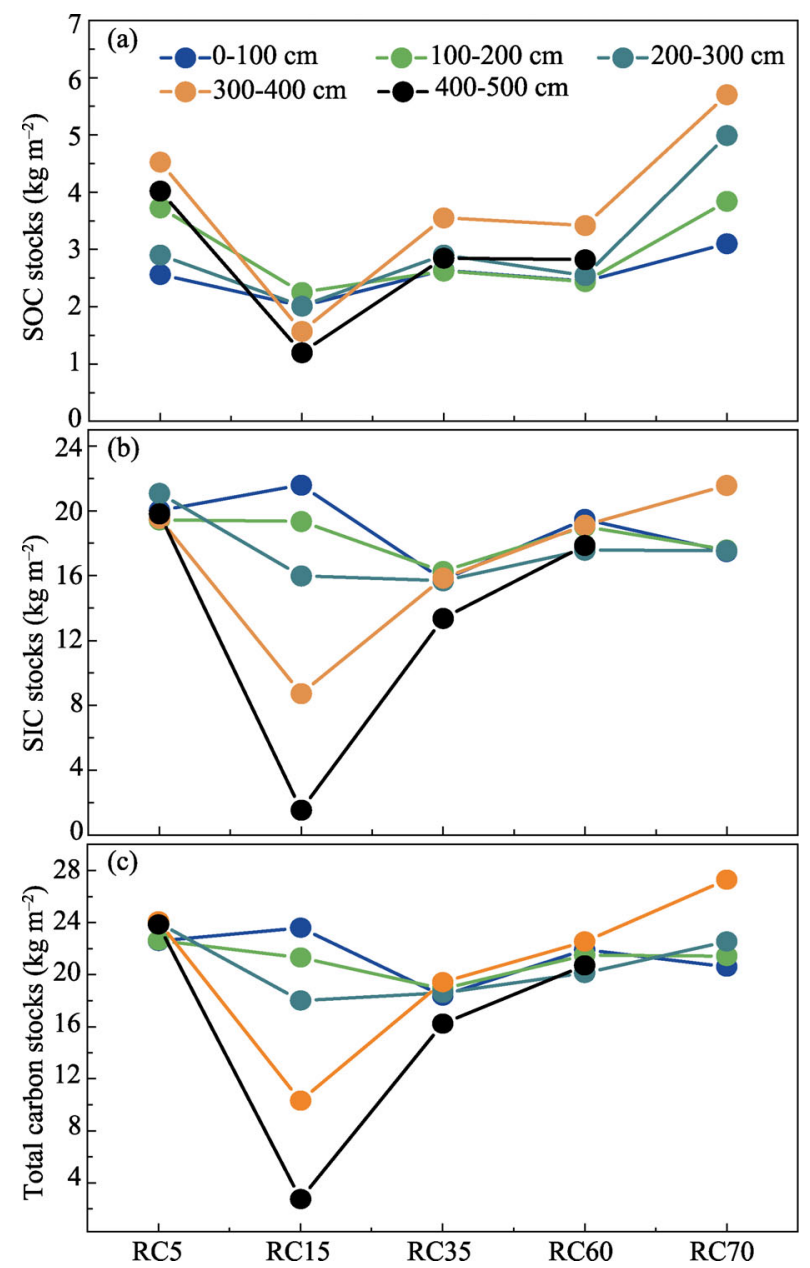

Figure 6 Changes in carbon stocks with time at different sub-layers: (a) SOC stocks, (b) SIC stocks, and (c) TC stocks at $100-\mathrm{cm}$ intervals

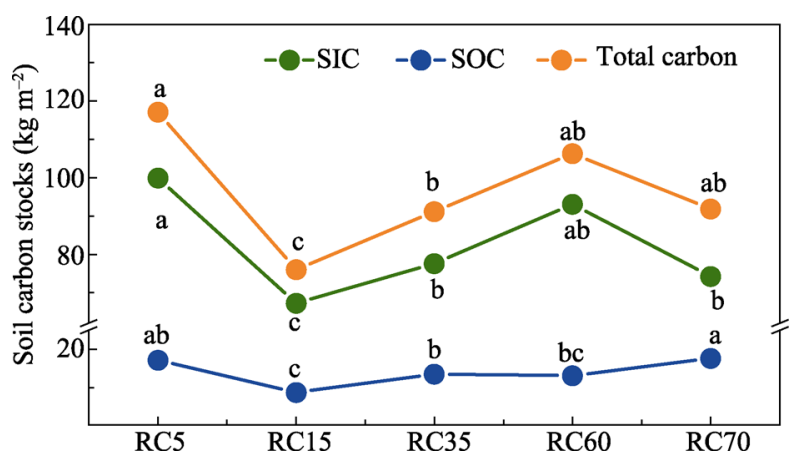

Figure 7 Changes in SOC, SIC, and TC stocks with time in $0-500 \mathrm{~cm}$ soil profiles

mainly in the form of inorganic $\mathrm{C}$ for the five land-use types (Figures 3 and 6). The density of the overall SIC stocks ranked in the following order: grassland $>$ forestland $>$ shrubland $>$ cropland $>$ gully land (Figure 3). The SIC spatial distribution of SIC stocks were similar to
The integral SOC stocks under RC5, RC15, RC35, RC60, and RC70 were $17.2,8.77,13.5,13.2$, and 18.1 $\mathrm{kg} \mathrm{m}{ }^{-2}$, respectively, and the SOC stocks at $100 \mathrm{~cm}$ intervals followed the same pattern: RC70 > RC5 > RC35 > RC60 > RC15 (Figure 6a). The lowest SOC stock was observed in $\mathrm{RC} 15$, the highest was observed in RC70; moreover, the SOC stock was slightly lower under RC60 than under RC35.

Different lowercase letters indicate significant differences $(p<0.05)$ among croplands under five different cultivation times.

Cultivation time significantly affected SOC stocks in reclaimed croplands, according to the two-way ANOVA $(p<0.05)$ (Table 2). If we ignore the stocks in RC5, a consistent temporal trend was observed, showing that SOC stocks increased gradually in the reclaimed croplands, which is in agreement with the result of Liu et al. (2017), who reported that SOC stocks increased with restoration time. SOC values in RC5 were significantly higher than in RC15 $(p<0.05)$ (Figure 7), suggesting that cultivation has led to soil C losses over at least 15 years, with SOC losses of approximately $49 \%$ of soil C stocks, whereas SOC stocks in RC70 increased $2.7 \%$ relative to RC5.

\subsubsection{SIC stocks}

SIC stocks ranged from 50.3 to $104.1 \mathrm{~kg} \mathrm{~m}^{-2}$, accounting for $84 \%-$ $89 \%$ of TC stocks (Figure 3 ) and were approximately six times greater than SOC stocks. The contribution to SIC stocks in the $0-500 \mathrm{~cm}$ soil layer was 
SOC stocks (Figures 4a and 4b). Natural vegetation also had higher SIC stocks than cropland. Both soil depth and land-use type influenced SIC stocks significantly $(p<0.05)$ (Table 2). There was no significant variation of SIC stocks among land-use types at a depth of 0-20 cm, and no clear pattern was observed at $20-400 \mathrm{~cm}$. Regarding the depth range from 400 to 500 $\mathrm{cm}$ in terms of land use, SIC ranked in the following order: grassland $>$ forestland $>$ shrubland $\approx$ cropland (Figure $5 \mathrm{c}$ ). In addition, SIC stocks in grassland and forestland increased with soil depth, whereas an opposite trend was observed for shrubland and cropland (Figure 5d).

Cultivation time significantly affected SIC stocks $(p<0.05)$ (Table 2). For example, a consistent decrease in SIC values with depth was observed for RC15, after which, values for the $0-200 \mathrm{~cm}$ section of the soil profile decreased slightly with time, while deep soil SIC values (i.e., at $200-500 \mathrm{~cm}$ ) increased with time (Figure $6 \mathrm{~b}$ ). Trends for TC stocks were similar, as they were dominated by the SIC component (Figures $5 \mathrm{c}$ and 6 ).

\section{Discussion}

\subsection{Sources of variation in SOC and SIC distributions under five land use types}

The overall C stocks in grassland, forestland, and shrubland were $23.8,15.0$, and $11.4 \mathrm{~kg} \mathrm{~m}^{-2}$, respectively; all higher than the $\mathrm{C}$ stocks in cropland, and gully land, where they were the lowest (Figure 3). In other words, grassland, forestland and shrubland all showed a higher capacity to fix $\mathrm{C}$ compared to cropland; these results are consistent with those of Ali et al. (2017) and Wang et al. (2016).

Different land-use types are associated with diverse plant communities that influence SOC due to variability in plant productivity, soil quality, and soil C turnover time (Esteban et al., 2000; Wiesmeier et al., 2012). In the present study, land use significantly influenced integral SOC stocks $(p<0.05)$ (Table 2). In particular, the grassland SOC-stock was highest among the five land-use types in the top $(0-60 \mathrm{~cm})$ soil (Figure $5 \mathrm{a})$, because grasses grow seasonally and die off every winter, leaving plant litter on the ground surface, facilitating the accumulation of organic $\mathrm{C}$ and rhizosphere microbiota, who use decaying organic matter as a source of energy.

As Deng et al. (2014) reported, biomass in cropland disturbed by human tillage activities tends to increase organic decomposition and C losses; therefore, cropland usually shows lower SOC contents than other land-use types. The present study showed that, although SOC content exhibited the same trends as described previously (Wang et al., 2016; Liu et al., 2017; Yang et al., 2018) (Table 3), in the cropland top soil layer (0-20 $\mathrm{cm})$, with SOC stocks slightly lower than in the grassland, and similar to those found at $20-400 \mathrm{~cm}$ depth; but significantly higher than SOC stocks of either grassland or forestland at depths of 400-500 cm $(p<0.05)$ (Figure 5a). This could be attributed to harvest practices of farmers in the area, whereby maize straw is allowed to lay fallow on the ground until November; this method reduces soil erosion and organic C losses, maintaining SOC reserves at a level comparable to those found in grassland or forestland. On the other hand, the calculated Pearson correlation coefficient showed that SOC was positively and significantly influenced by SWC $(p<0.05)$, and it was directly related to BD (Equation 1). BD was significantly higher in cropland than in either grassland or forestland $(p<0.05)$ (Table 1). Furthermore, we found higher SWC in cropland than in 
other land-use types, as dissolved OC transformed by organic manure might be leached from the surface and subsequently transported into deeper soil layers by groundwater (Wang et al., 2016; Zhu et al., 2018), resulting in relatively high SOC stocks under farmlands in deep soils.

We also found that some SIC was stored in the subsoils of grassland and forestland (Figure $5 \mathrm{~d}$ ). This could be attributed to the inherent high water-conservation capacity of these land-uses, allowing a greater proportion of water to percolate downward and eventually form carbonates that accumulate in the deeper soil layers.

\subsection{Management strategy of carbon under reclaimed croplands}

SOC stocks decreased from RC5 to RC15 and then steadily increased up to a maximum value in RC70 (Figure 6a). The second higher, overall initial SOC stocks were observed in RC5 (Figure 6a). This could be attributed to the relatively large amounts of C introduced in the soil when organic manure was used to fertilize the new cropland. After approximately 15 years under the constant influence of agricultural activities, a large amount of $\mathrm{C}$ is decomposed and readily removed by rainwater as it moves through the soil. This presumably accounts for the observed SOC reduction in $\mathrm{RC} 15$, reflecting conditions that are not conducive to $\mathrm{C}$ fixation. Total SOC stocks subsequently increased with time in RC35 and RC60, which were not significantly different from one another $(p>0.05)$, while SOC stocks in RC35 were slightly higher than in RC60 (Figures 5a and 6). This small difference may have been caused by the introduction of a nursery in RC35, which enhanced soil $\mathrm{C}$ sequestration.

The integral stocks of SOC and SIC were consistently lower in cropland than in grassland, forestland or shrubland (Table 1), probably because of soil $\mathrm{C}$ loss during ploughing after reclamation (Deng et al., 2014), and the ability of crops to fix $\mathrm{C}$ is lower compared to that of grass or forest. Several scientists have recommended enclosing croplands and allowing the restoration of natural grasslands to increase SOC stocks (Albaladejo et al., 2013; Liu et al., 2017) to avoid the abovementioned problem. However, land cultivation in support of the growing human population in the CLP region is already insufficient. Therefore, we can neither enclose all the cropland, nor plant reclaimed croplands with nurseries or turn them into grasslands. Nevertheless, Li et al. (2016) and Cardinael et al. (2017) demonstrated the advantages of alternative agroforestry systems to efficiently enhance SOC stocks in agricultural lands to mitigate climate change. Our results are consistent with such an approach. Therefore, we advise local governments to pursue turf culture or nursery establishment in newly reclaimed croplands for some years, followed by the adoption of an agroforestry approach to increase both grain production and C sequestration. Such programs should be continuously monitored to gain a comprehensive understanding of the evolution of SOC and SIC inventories with cultivation time.

\section{Conclusions}

Both SOC and SIC should be estimated over broad areas to evaluate C stocks and their relationship with different land-use types on the CLP. 1) Grassland, shrubland, and forestland showed the greatest capacity to accumulate $\mathrm{C}$ in soil profiles from the surface to a depth of $500 \mathrm{~cm}$, compared to either cropland or gully land. 2) SIC stocks in these five land-use 
types contributed to $84 \%-89 \%$ of TC stocks, which was much higher than SOC stocks. 3 ) Moreover, the amounts of SOC and SIC in deep soil layers $(100-500 \mathrm{~cm})$ were greater than those in the $0-100 \mathrm{~cm}$ soil depth range. Moreover, it is necessary to accurately quantify the amount of $\mathrm{C}$ sequestered and cycled with time. Our data clearly show that cultivation time significantly influenced SOC and SIC stocks. 4) Soils that were reclaimed 15 years ago for cropping are regarded as poor soils that can optimal for neither crop growth nor $\mathrm{C}$ fixation. 5) Planting a small nursery in the RC35 cropland is better than planting corn to sequester C. 6) Cultivation has led to $C$ losses equivalent to approximately 60 years of $\mathrm{C}$ accumulation, with a TC loss of approximately $23 \%$ in the $0-500 \mathrm{~cm}$ soil profile on the CLP. Therefore, we suggest that local governments consider laying sod or establishing nurseries in newly reclaimed croplands for several years, prior to introducing grain cropping or developing an agroforestry system whereby grain production and $\mathrm{C}$ sequestration might be fostered.

\section{Acknowledgements}

We would like to express sincere thanks to the Belt \& Road Center for Earth Environment Studies and CAS Key Technology Talent Program.

\section{References}

Adams J M, Faure H, Fauredenard L et al., 1990. Increases in terrestrial carbon storage from the Last Glacial Maximum to the present. Nature, 348: 711-714.

Albaladejo J, Ortiz R, Garcia-Franco N et al., 2013. Land use and climate change impacts on soil organic carbon stocks in semi-arid Spain. Journal of Soils and Sediments, 13: 265-277.

Ali S, Begum F, Hayat R et al., 2017. Variation in soil organic carbon stock in different land uses and altitudes in Bagrot valley, northern Karakoram. Acta Agriculturae Scandinavica Section B-Soil and Plant Science, 67(6): $551-561$.

Batjes N H, 1996. Total carbon and nitrogen in the soils of the world. European Journal of Soil Science, 47(2): $151-163$.

Batjes N H, 2016. Harmonized soil property values for broad-scale modelling (wise30sec) with estimates of global soil carbon stocks. Geoderma, 269: 61-68.

Bi X, Li B, Nan B et al., 2018. Characteristics of soil organic carbon and total nitrogen under various grassland types along a transect in a mountain-basin system in Xinjiang, China. Journal of Arid Land, 10(4): $612-627$.

Cardinael R, Chevallier T, Cambou A et al., 2017. Increased soil organic carbon stocks under agroforestry: A survey of six different sites in France. Agriculture Ecosystems \& Environment, 236: 243-255.

Civeira G, 2013. Distribution of soil organic and inorganic carbon by soil taxa in the central eastern Pampas of Buenos Aires. Soil Science, 178(3): 120-127.

Civeira G, 2016. Soil inorganic carbon in pampean agroecosystems: Distribution and relationships with soil properties in Buenos Aires Province. Soil Research, 54(7): 777-786.

Deng L, Liu G B, Shangguan Z P, 2014. Land-use conversion and changing soil carbon stocks in China's 'Grain-for-Green' Program: A synthesis. Global Change Biology, 20(11): 3544.

Díaz-Hernández J L, 2010. Is soil carbon storage underestimated? Chemosphere, 80(3): 346-349.

Esteban G, Jobbágy E G, Jackson R B, 2000. The vertical distribution of soil organic carbon and its relation to climate and vegetation. Ecological Applications, 10(2): 423-436.

Eswaran H, 1993. Organic carbon in soils of the world. Soil Scisocamj, 57(1): 269-273.

Fu D L, Liu M Y, Liu L et al., 2014. Organic carbon density and storage in different soils on the Loess Plateau. Arid Zone Research, 31(1): 44-50. (in Chinese)

Grimm R, Behrens T, Märker M et al., 2008. Soil organic carbon concentrations and stocks on Barro Colorado Island: Digital soil mapping using random forests analysis. Geoderma, 146(1/2): 102-113.

Han X Y, Gao G Y, Chang R Y et al., 2018. Changes in soil organic and inorganic carbon stocks in deep profiles following cropland abandonment along a precipitation gradient across the Loess Plateau of China. Agriculture Ecosystems \& Environment, 258: 1-13.

Harper R J, Tibbett M, 2013. The hidden organic carbon in deep mineral soils. Plant and Soil, 368(1/2): 641-648.

Jaiarree S, Chidthaisong A, Tangtham N et al., 2011. Soil organic carbon loss and turnover resulting from forest conversion to maize fields in eastern Thailand. Pedosphere, 21(5): 581-590. 
Li C L, Li Q, Zhao L et al., 2016. Land-use effects on organic and inorganic carbon patterns in the topsoil around Qinghai Lake Basin, Qinghai-Tibetan Plateau. Catena, 147: 345-355.

Lin Z B, Zhang R D, 2012. Dynamics of soil organic carbon under uncertain climate change and elevated atmospheric $\mathrm{CO}_{2}$. Pedosphere, 22(4): 489-496.

Liu S L, Tang Y H, Zhang F W et al., 2017. Changes of soil organic and inorganic carbon in relation to grassland degradation in northern Tibet. Ecological Research, 32(3): 1-10.

Liu W G, Wei J, Cheng J M et al., 2014. Profile distribution of soil inorganic carbon along a chronosequence of grassland restoration on a 22-year scale in the Chinese Loess Plateau. Catena, 121: 321-329.

Liu Y, Dang Z Q, Tian F P et al., 2017. Soil organic carbon and inorganic carbon accumulation along a 30-year grassland restoration chronosequence in semi-arid regions (China). Land Degradation \& Development, 28(1): 189-198.

Ma X X, Xu M X, Yang K, 2012. Soil organic carbon mineralization of black locust forest in the deep soil layer of the hilly region of the Loess Plateau, China. Environmental Sciences, 33(11): 3893-3900. (in Chinese)

Miltner A, Bombach P, Schmidt-Brücken B et al., 2012. Som genesis: Microbial biomass as a significant source. Biogeochemistry, 111(1-3): 41-55.

Rumpel C, Amiraslani F, Koutika L S et al., 2018. Put more carbon in soils to meet paris climate pledges. Nature, 564: 32-34.

Rumpel C, Kögel-Knabner I. 2011. Deep soil organic matte: A key but poorly understood component of terrestrial C cycle. Plant and Soil, 338(1/2): 143-158.

Schlesinger W H, 1982. Carbon storage in the caliche of arid soils: A case study from Arizona. Soil Science, 133(4): 247-255.

Sommer R, Denich M, Vlek P L G, 2000. Carbon storage and root penetration in deep soils under small-farmer land-use systems in the eastern Amazon region, Brazil. Plant and Soil, 219(1/2): 231-241.

Trumbore S, 2009. Radiocarbon and soil carbon dynamics. Annual Review of Earth \& Planetary Sciences, 37: 47-66.

Trumbore S E, 1997. Potential responses of soil organic carbon to global environmental change. Proceedings of the National Academy of Sciences of the United States of America, 94(16): 8284-8291.

Wang K B, Ren Z P, Deng L et al., 2016. Profile distributions and controls of soil inorganic carbon along a 150-year natural vegetation restoration chronosequence. Soilence Society of America Journal, 80(1): 193-202.

Wang L, Shao M A, Zhang Q F, 2004. Distribution and characters of soil dry layer in north Shaanxi Loess Plateau. Chinese Journal of Applied Ecology, 15(3): 436-442.

Wang T, Kang F F, Cheng X Q et al., 2016. Soil organic carbon and total nitrogen stocks under different land uses in a hilly ecological restoration area of North China. Soil \& Tillage Research, 163: 176-184.

Wang Y G, Li Y, Ye X H et al., 2010. Profile storage of organic/inorganic carbon in soil: From forest to desert. Science of The Total Environment, 408(8): 1925-1931.

Wang Y Q, Han X W, Jin Z et al., 2016. Soil organic carbon stocks in deep soils at a watershed scale on the Chinese Loess Plateau. Soil Science Society of American Journal, 80: 157-167.

Wang Y Q, Shao M A, Zhang C C et al., 2015. Soil organic carbon in deep profiles under Chinese continental monsoon climate and its relations with land uses. Ecological Engineering, 82: 361-367.

Wiesmeier M, Sporlein P, Geuss U et al., 2012. Soil organic carbon stocks in southeast Germany (Bavaria) as affected by land use, soil type and sampling depth. Global Change Biology, 18(7): 2233-2245.

Wu H B, Guo Z T, Gao Q et al., 2009. Distribution of soil inorganic carbon storage and its changes due to agricultural land use activity in China. Agriculture Ecosystems \& Environment, 129(4): 413-421.

$\mathrm{Xu} \mathrm{L}, \mathrm{Yu} \mathrm{G}, \mathrm{He} \mathrm{N}, 2019$. Increased soil organic carbon storage in Chinese terrestrial ecosystems from the 1980s to the 2010s. Journal of Geographical Sciences, 29(1): 49-66.

Yang F, Huang L M, Yang R M et al., 2018. Vertical distribution and storage of soil organic and inorganic carbon in a typical inland river basin, Northwest China. Journal of Arid Land, 10(2): 183-201.

Zeng J, Yue F-J, Wang Z-J et al., 2019. Quantifying depression trapping effect on rainwater chemical composition during the rainy season in karst agricultural area, southwestern China. Atmospheric Environment, 218: 116998.

Zhang F, Wang X, Guo T et al., 2015. Soil organic and inorganic carbon in the loess profiles of Lanzhou area: Implications of deep soils. Catena, 126: 68-74.

Zhang S, Xu M X, Zhang Y F et al., 2014. Effects of land use change on storage of soil organic carbon in deep soil layers in the hilly Loess Plateau region, China. Acta Scientiae Circumstantiae, 34: 3094-3101.

Zhang S R, Sun B, Zhao Q G et al., 2004. Temporal-spatial variability of soil organic carbon stocks in a rehabilitating ecosystem. Pedosphere, 14(4): 501-508.

Zhao Y L, Wang Y Q, Wang L et al., 2019. Exploring the role of land restoration in the spatial patterns of deep soil water at watershed scales. Catena, 172: 387-396.

Zhu G F, Pan H X, Zhang Y et al., 2019. Relative soil moisture in China's farmland. Journal of Geographical Sciences, 29(3): 334-350.

Zhu Q, Castellano M J, Yang G S, 2018. Coupling soil water processes and the nitrogen cycle across spatial scales: Potentials, bottlenecks and solutions. Earth-Science Reviews, 187: 248-258. 